Anatolia: Turizm Araştırmaları Dergisi, Cilt 32, Sayı 2, Güz: 267 - 303, 2021

Copyright (C) 2021 anatolia

Bütün hakları saklıdır ISSN: 1300-4220 (1990-2021)

https://doi.org/ 10.17123/atad.1024324

\title{
Turizm Tarihinin Kaynakları-2
}

Murat HANILÇE

Tokat Gaziosmanpaşa Üniversitesi Fen Edebiyat Fakültesi
Anatolia'nın geçtiğimiz sayısından itibaren ülkemizde son zamanlarda giderek yaygınlık kazanan Turizm Tarihine malzeme sağlayan çeşitli kaynakları tanıtmaya başlamıştık. Bu sayıda da arşivler ve seyahatnameler üzerindeki yolculuğumuza devam edeceğiz. Köşemizin bu ikinci bölümünde Osmanlı Arşivi ve Orta Çağ seyyahlarına değineceğiz.

\section{KISIM: TURIZM TARIHI ARAŞTIRMALARI içiN ARŞiVLER-2}

Turizm ve Turizm Tarihi Araştırmaları İçin Köklü ve Dinamik Bir Arşiv: BOA (Cumhurbaşkanlığı Osmanlı Arşivi)

Osmanlı Arşivleri (BOA) ${ }^{1}$, Osmanlı Devleti zamanında üretilip Türkiye Cumhuriyeti'ne intikal etmiş evrakların muhafaza edildiği, tasnif çalışmaları yapılarak gün yüzüne çıkarıldığı ve araştırmacıların hizmetine sunulduğu bir kurumdur. Osmanlı Dönemi'nde Hazine-i Evrak olarak anılan Osmanlı Arşivleri, devletin ulaştığı geniş sınırlar düşünüldüğünde, günümüz Balkan Devletleri ile Orta Doğu Devletleri, Afrika ülkeleri ve onların komşusu olduğu devletler de hesaba katıldığında 40'tan fazla ülkenin tarihi mirasını barındırmaktadır.

Arşivde 95 milyonun üzerinde belge vardır. Bu belgeler içerisinde 400 bini aşkın defter bulunmaktadır. Arşivin mevcut raf uzunluğu 120 kilometreyi aşmaktadır. Bu yönüyle dünyanın en zengin arşivlerinden birisidir. Osmanlı Devleti'nin merkez teşkilatını meydana getiren

\footnotetext{
${ }^{1}$ Osmanlı Arşivi Uzmanı Doktora öğrencim Ümit Baki Erdem'e bu kısmı hazırlarken sağladı̆̆ı her türlü katkı için teşekkür ederim.
}

Divan-ı Hümâyûn, Bâb-ı Defterî, Bâb-ı Âsafì, Bâbıâlî ve bunların çeşitli daire ve kalemlerine ait sicil, defter ve vesikaları, yani Osmanlı Devleti'nden intikal eden en zengin ve çeşitli arşiv malzemesini ihtiva etmesi sebebiyle Osmanlı Devleti'nin ana arşivi hüviyetini taşımaktadır.

Osmanlı Devleti'nin kuruluş dönemine ait oldukça az sayıda belgeye sahip olunsa da I. Süleyman (Kanunî) Devri'nden itibaren artan sayıda defterlerin ve evrakın günümüze kadar intikal ettiği ve saklandığı Osmanlı Arşivleri'nin modern anlamda alt yapısı yine Osmanlı Devri'nde kurulmuştur. 1845 yılında devrin Maliye Nazırı Safveti Paşa'nın girişimleriyle başlayan arşivin kurumsallaşma serüveni 1837 yılında Maliye Nezâreti'ne dönüştürülmüş olan Bâb-ı Defterî döneminden kalan ve Topkapı Sarayı'ndaki Enderûn Hazinesi'nde saklanan milyonlarca belgenin günümüz tasnif anlayışına uygun olarak, kalemlerine göre ayrılıp depolara konularak devam etmiş, nihayetinde 1846 yılında Hazine-i Evrak'ın kurulması ile tam anlamıla modern Osmanlı Arşivi kurumunun temeli inşa edilmiştir.

1849'da yayımlanan Hazine-i Evrak Nizamnamesi ile Türk arşivciliğinin yasal temelleri atılmış ve Osmanlı Devleti'nin sonuna kadar bu isimle anılmaya devam etmiştir. Türkiye Cumhuriyeti'ne miras kalan bu zengin arşiv Başvekâlet Evrak ve Hazine-i Evrak Müdürlüğ̈̈, 1943'te Başvekâlet Arşiv Umum Müdürlüğü, 1984'te Devlet Arşivleri Genel Müdürlüğ̈̈ isimleri altında 2018 yılına kadar devam etmiş; aynı yıl çıkarılan KHK (Kanun Hükmünde Kararname) ile Cumhurbaşkanlığı Devlet Arşivleri Başkanlığı adını almıştır. 
Nasıl ki 1846 yılında Hazine-i Evrak'ın kurulması, arşiv evrakları için bir dönüm noktası ise Cumhuriyet Türkiye'sine miras kalan bu kurum için önemli bir diğer dönüm noktasını Cumhurbaşkanı Turgut Özal'ın arşive olan ilgisi ve talimatları teşkil eder. Alınan çok sayıda personel ve sağlanan maddi-manevi imkânlarla arşivde tasnif çalışmaları hızlandırılmış; çürümeye terk edilmiş arşiv evrakı İstanbul Hasdal, Beyazıt, Pertevniyal Lisesi, Sultanahmet, Süleymaniye ve Çapa'da arşiv uzmanlarının eşsiz çabalarıyla gün yüzüne çıkarılmıştır.

Osmanlı Arşivi İstanbul'da uzun yıllar Sultanahmet'teki binalarında hizmet vermiştir. Kağıtha$n e$ 'deki arşiv külliyesi inşası 2013'te tamamlanınca buraya taşınmıştır. Modern arşivcilik teknikleri ve belge saklama koşullarına sahip bir külliye șeklinde tasarlanan yeni arșiv yapıları 122 bin metrekarelik bir alanda yayılmıştır. Yapılar, merkezi otomasyon sistemleriyle kontrol edilen 800'ü aşkın kameraya sahiptir. Arşiv evrakı sadece ilgili uzmanlarca parmak izi ile girilebilen, isısı ve nemi anlık kontrol edilen depolarda muhafaza edilmektedir. Bu depolardaki Osmanlı arşiv mirası Dünya arşivcilik uygulamalarında kabul edilen $18-21^{\circ} \mathrm{C}$ arası 1sı ve yüzde $45-55$ arası nem oranlaru ile korunmaktadır.

Osmanlı Arşivlerinin ait olduğu dönemin hukukî yapısı, başka bir deyişle ait olduğu Osmanlı Devleti sona ermiştir. Böylece arşivin ait olduğu devletin evrak üretimi durmuştur. Bununla birlikte, Osmanlı Devleti'nin ortadan kalkması ve evrak üretiminin durmasına bakarak arşivin statik bir yapıya sahip olduğu izlenimine kapılmamak gerekir. Her ne kadar Osmanlı Devleti sona erse de Osmanlı Arşivi halen dinamik bir yapıya sahiptir. Arşive dışarıdan hibe edilen, satın alınan ve arşiv kataloglarında HSD koduyla yer alan evrakların yanında Devlet Arşivleri Başkanlığı ve ilgili kurumların iş birliği ile Makedonya, Bosna-Hersek, Arnavutluk ve Kuzey Kıbrıs Türk Cumhuriyeti'ndeki Osmanlı Dönemi'ndeki evrakın dijital görüntülerinin Osmanlı Arşivi'ne aktarılması ile bu dinamizm korunmaktadır.

Arşivde I. Süleyman'dan (Kanunî) itibaren padişahların el yazıları, diğer devletlerle yapılan anlaşma metinleri, Osmanlı Devleti'nin son dönemine ait günümüzde akademide ve halk nezdinde etkileri hala görülen ve tartışılagelen önemli evraklar vardır. Küçük Kaynarca Antlaşması, Karlofça Antlaşması, Sened-i İttifak, Tanzimat Fermanı, Islahat Fermanı, Balta Limanı Antlaşması, Ayastefanos Antlaşması, Uşi Antlaşması, Cihad-ı Ekber Fetvası, Mondros Ateşkes Antlaşması, Mustafa Kemal Paşa'nın Dokuzuncu Ordu Müfettişliği'ne tayini hakkında Harbiye Nezareti'nin talebi ve VI. Mehmed Vahdeddin'in İradesi, Amasya Genelgesi Beyannamesi, Erzurum ve Sivas Kongreleri Beyannameleri, Misak-1 Milli Beyannamesi, Temsil Heyeti Reisi Mustafa Kemal'in TBMM'nin açılması için yaptığı çağrı gibi yakın tarihimizin dönüm noktalarını teşkil eden evraklar bunlardan önemli birkaçıdır.

Osmanlı Arşivi daha çok akademik çalışmalar için eşsiz ve temel bir kaynak sağlayıcı gibi görünse de arşivin sıradan bir vatandaşı ilgilendiren yönleri de vardır. Soy kütüğü araştırmalarına son dönemde giderek artan ilgi bu tezi desteklemektedir. Kişilerin geçmişe olan merakı, nereden ve hangi bölgeden geldikleri konusundaki merak ile son dönemlerde Osmanlı Türkçesine artan ilgi birleştiğinde Osmanlı Arşivleri'ne müracaatların arttı̆̆ı görülmektedir. Osmanlı Devleti'nin 1831 yılında ilk kez uyguladığı nüfus sayımları ve bunlara ait 18 bini aşkın defter ile 1845 yılından başlayarak tutulmaya başlanan ve sayısı 17 bini aşan Temettüat Defterleri atalarını merak eden araştırmacılara zengin kaynak sunmaktadır.

İstanbul Kağıthane'deki Osmanlı Arşivi'nin ziyaretçilere sunduğu en ilgi çekici bölümlerinden birisi de müze kısmıdır. Hazine-i Evrak Daimi Sergisi adı altında hizmet veren bu müzede daha önce zikredilen antlaşma metinlerinin görsel malzemelerinin yanı sıra padişahların ve maiyetindeki eşleri ve kızlarının el yazılarının orijinal belgelerle teşhirleri ile Fatih Sultan Mehmed Han'ın Bosna Fermanı, Kanuni Sultan Süleyman'ın el yazısı, Revan Adaletnamesi, Sultan III. Murad'ın İngiltere'ye yardım için donanmanın gönderileceğini bildiren mektubu, Sultan II. Abdülhamid'in Boğaz Köprüsü Projesi'nin çizimlerinin yanında zengin tezhiplerle süslenmiş fermanlar, beratlar, mühürler, madalyalar, resimler, arşiv 
Turizm Tarihi İncelemeleri

Tablo 1. Osmanlı Arşivinde Turizme Dair Bazı Belgelerin Tasnifi ve Belge Sayıları

\begin{tabular}{|c|c|c|c|c|c|c|c|}
\hline Anahtar Kelime & Belge SayısI & Anahtar Kelime & $\begin{array}{l}\text { Belge } \\
\text { SayısI }\end{array}$ & Anahtar Kelime & Belge SayısI & Anahtar Kelime & Belge SayısI \\
\hline Araba & 16656 & Gazino & 770 & Karantina & 6247 & $\begin{array}{l}\text { Sefine (Gemi)+Sefain } \\
\text { (Gemiler)+Vapur }\end{array}$ & $\begin{array}{l}6236+8143+540 \\
09\end{array}$ \\
\hline $\begin{array}{l}\text { Asar-ı atik[a]+antika+eski } \\
\text { eser+arkeoloji+hafriyat }\end{array}$ & $\begin{array}{l}3431+698+ \\
1431+120+ \\
6821\end{array}$ & Geçiş & 7669 & $\begin{array}{l}\text { Kafile+Karban+Kerv } \\
\text { an }\end{array}$ & $516+48+394$ & Seyahat+Seyehat & $11536+107$ \\
\hline Aşevi+Aşhane & $6+18$ & Gelecek & 20315 & Kasr+Köşk & $9049+2129$ & $\begin{array}{l}\text { Seyahat Pusulası+Seyahat } \\
\text { Ruhsatnamesi }\end{array}$ & $10+9$ \\
\hline $\begin{array}{l}\text { Atebat-ı Aliyat+Atebat-ı } \\
\text { Ulya+Atebe-i Ulya }\end{array}$ & $28+12+398$ & Gelip giden & 1687 & Kayık & 7262 & $\begin{array}{l}\text { Seyahat-ı } \\
\text { Hümayun+Seyahat-ı } \\
\text { Seniyye+Seyahat-ı Şahane }\end{array}$ & $210+110+281$ \\
\hline Avdet+Geliş+Dönüş & $\begin{array}{l}17642+293 \\
1+4726\end{array}$ & Gemi & 14975 & Kebapcı & 115 & $\begin{array}{l}\text { Seyr+Seyr ü } \\
\text { sefer+Seyrüsefer }\end{array}$ & $5474+1126+426$ \\
\hline Azimet+Gidiş & $\begin{array}{l}17127+337 \\
1\end{array}$ & $\begin{array}{l}\text { Geşt ü güzar+Keşt } \\
\text { ü güzar (gezip } \\
\text { dolaşma) }\end{array}$ & $397+15$ & Kervansaray & 446 & $\begin{array}{l}\text { Seyyah+Seyyahin } \\
\text { (Seyyahlar) }\end{array}$ & 1075 \\
\hline Bahri-bahr-bahren & 30561 & Gezecek & 166 & Kiler+Kiler-i amire & $29526+846$ & $\begin{array}{l}\text { Sila-i Rahim (Akraba } \\
\text { ziyareti) }\end{array}$ & 75 \\
\hline Balos+Baloz+Meyhane & $53+12+555$ & Gezen & 653 & Lokanta+Restoran & $192+5$ & Sinema & 258 \\
\hline Bargir+Beygir+Esb & $\begin{array}{l}6318+6364 \\
+498 \\
\end{array}$ & Gezi & 557 & $\begin{array}{l}\text { Lostarya (Küçük } \\
\text { han-otel) }\end{array}$ & 3 & Sirk & 118 \\
\hline Berr+Berren & $286+433$ & Gidecek & 20313 & $\begin{array}{l}\text { Matbah+Mutfak+M } \\
\text { atbah-ı amire (saray } \\
\text { mutfağı) }\end{array}$ & $\begin{array}{l}14451+1502+ \\
8627\end{array}$ & $\begin{array}{l}\text { Surre (Kutsal topraklara } \\
\text { yollanan hediyeler) }\end{array}$ & 11780 \\
\hline Bilet & 3069 & Götürecek & 1017 & $\begin{array}{l}\text { Mekari+Mekareci+ } \\
\text { Mekkari+Mekkarici+ } \\
\text { Kiracı (Nakliyeci) }\end{array}$ & $\begin{array}{l}1532+19+21+ \\
1303+1216\end{array}$ & Şekerci & 619 \\
\hline Binek & 534 & Gümrüğü+gümrük & $\begin{array}{l}70330+7 \\
0277 \\
\end{array}$ & $\begin{array}{l}\text { Menzil+Konak } \\
\text { (Posta durağı) }\end{array}$ & $14335+21196$ & Şerbetci & 330 \\
\hline Birahane & 65 & $\mathrm{Hac}+\mathrm{Hacc}$ & $\begin{array}{l}29593+1 \\
541\end{array}$ & Menzil beygiri & 2304 & $\begin{array}{l}\text { Şimendifer+Tren+Tramvay } \\
\text { +Katar }\end{array}$ & $\begin{array}{l}6343+2862+246 \\
3+2184\end{array}$ \\
\hline Cisr+Köprü & $\begin{array}{l}7657+1135 \\
5\end{array}$ & Hac emini & 4353 & $\begin{array}{l}\text { Mihmannüvaz } \\
\text { (Misafir ağırlayan) }\end{array}$ & 6 & Şirket-i Hayriye & 2894 \\
\hline Çeşme & 8472 & Hac müjdeci & 37 & Misafir+Misafirhane & $4814+739$ & $\begin{array}{l}\text { Tarik (Kara yolu)+Turuk } \\
\text { (Kara yolları)+Şose+Yol }\end{array}$ & $\begin{array}{l}9341+3022+229 \\
4+64144\end{array}$ \\
\hline Çırağan & 2827 & $\begin{array}{l}\text { Hacl+Hüccac } \\
\text { (Hacılar) }\end{array}$ & $\begin{array}{l}131418+ \\
1849\end{array}$ & Muhallebici & 78 & $\begin{array}{l}\text { Tayinat } \\
\text { (Yiyecekler)+Yemek+Yiyece } \\
\text { k }\end{array}$ & $\begin{array}{l}30752+219+272 \\
4\end{array}$ \\
\hline Demiryol & 32617 & Hamam & 6151 & Mürur (Geçip gitme) & 15617 & Tenezzüh (Gezinti) & 276 \\
\hline Deniz Hamamı & 250 & Han & 106271 & Mürur tezkire/leri & 494 & Tercüman & 14055 \\
\hline $\begin{array}{l}\text { Debend }+ \text { Derbent+Geçid+Geçi } \\
t+\text { Maabir+MeabirMemerr }+D \\
\text { erbentçi }\end{array}$ & $\begin{array}{l}2568+601+ \\
749+978+3 \\
56+1117+2 \\
3+111\end{array}$ & Harekat+Hareket & $\begin{array}{l}9011+54 \\
665\end{array}$ & Mürurname & 3 & $\begin{array}{l}\text { Teşebbüsat-ı Temsiliye-i } \\
\text { Osmani Anonim Şirketi }\end{array}$ & 6 \\
\hline Deve+Şütür & $\begin{array}{l}2729+3031 \\
8\end{array}$ & $\begin{array}{l}\text { Haremeyn+Hicaz+ } \\
\text { Medine+Mekke }\end{array}$ & $\begin{array}{l}17813+3 \\
0054+21 \\
377+195 \\
96\end{array}$ & $\begin{array}{l}\text { Müskirat (Alkollü } \\
\text { içkiler) }\end{array}$ & 4029 & Tezkire & 46959 \\
\hline Dondurma & 25 & Harita & 3948 & Müze & 4389 & Tezkiresiz seyahat & 230 \\
\hline $\begin{array}{l}\text { Ebna-i Sebil (yolcular, } \\
\text { seyyahlar) }\end{array}$ & 79 & $\begin{array}{l}\text { Hayvan+Hayvanat } \\
\text { +Hayvanat-I } \\
\text { Ehliye }\end{array}$ & $\begin{array}{l}16564+7 \\
902+842\end{array}$ & Nafia (Bayındırlık) & 35426 & Topkapı Sarayı & 4468 \\
\hline $\begin{array}{l}\text { Ecnebi (yabancı)+Ecanib } \\
\text { (yabanclar) }\end{array}$ & $\begin{array}{l}21068+101 \\
4\end{array}$ & Helvacı+Helvayi & $566+222$ & Nakil & 10078 & Transit & 1153 \\
\hline Eğlence & 169 & İmaret & 12836 & Nakliye & 28487 & Turist+Turistik+Turizm & $104+36+7$ \\
\hline Ekmek+Fodula+Ekmekçi & $\begin{array}{l}8759+1466 \\
+3468\end{array}$ & İrsal (Göndermek) & 55932 & Otomobil & 1660 & Vasıl (Ulaşan) & 7695 \\
\hline $\begin{array}{l}\text { Esna-yı rah (yolculuk } \\
\text { esnasında) }\end{array}$ & 260 & İsal (Ulaştırma) & 2661 & Panayır & 1863 & Vize-vize resmi & 16109 \\
\hline Ester+Katır & $\begin{array}{l}1873+3052 \\
1\end{array}$ & İskele+Liman & $\begin{array}{l}5425+22 \\
329\end{array}$ & Pasaport+Pasavan & $25973+1128$ & $\begin{array}{l}\text { Yol emri+yol hükm-i } \\
\text { şerifi+yol hükmü+yol } \\
\text { mektubu }\end{array}$ & $\begin{array}{l}1015+75+667+1 \\
203\end{array}$ \\
\hline Fuar & 516 & İzin tezkeresi & 44 & Pastacl & 22 & Yolcu & 7422 \\
\hline Galata & 23180 & Kahvaltı & 48 & Saray & 27722 & $\begin{array}{l}\text { Zair } \\
\text { (Ziyaretçi)+Zuvvar+Züvvar } \\
\text { (Zairin çoğulu) }\end{array}$ & $23+174+211$ \\
\hline Garson & 56 & Kaplıca & 164 & Sayfiye+Yazlık & $196+699$ & Ziyaret & 13377 \\
\hline
\end{tabular}


evrakının saklanmasında kullanılan torbalar, sandıklar ve paralar gibi çok zengin tarihi malzemeler sunulmaktadir.

Devlet Arşivleri Başkanlığı Osmanlı Arşivi'nde, 1 Mart 2002 tarihli 24682 sayılı Resmî Gazetede yayımlanan "Devlet Arşivlerinde Araştırma ve İnceleme Yapmak İsteyen Türk veya Yabancı Uyruklu Gerçek veya Tüzel Kişilerin Tabi Olacakları Esaslara" göre üye olunarak araştırma yapılır.

Osmanlı Arşivi'nde Osmanlı Devleti'nin kuruluşundan itibaren Türkiye Cumhuriyeti'nin kuruluşuna kadarki döneme ait Osmanlı Devleti merkez kurumları ile taşra idareleri arasında yapılan yazışmalar, Türkiye toprakları dışındaki Osmanlı sinırları üzerinde kurulu 40 civarında devletin tarihine ait kayıtlar, Osmanlı Devleti'nin diğer yabancı ülkelerle olan siyasi ve ticari ilişkilerine ait belgeler, devlet idaresi ile ilgili oluşturulan kanun, yönetmelik, nizamname gibi mevzuat kayıtları, devlet görevlilerinin tayin, terfi ve azil kayıtları, bazı dönemlerdeki devlet memurlarının sicil kayıtları, arazi tahrir kayıtları, timar, zeamet ve has gibi toprak kullanımına ait kayıtlar, vakıflara ait vakfiye, muhasebe, görevlendirme (tevcih, tevliyet vb.) kayıtları bulunmaktadır.

Osmanlı Arşivlerinin Turizm Tarihi ve Turizme Dair Kullanımı Üzerine Bir Değerlendirme: Osmanlı Arşivlerindeki belgeler arşivin sitesinde bulunan belge tarama sisteminden taranabilmektedir. Ayrıca belgelerin önemli bir kısmının dijital kopyaları online olarak araştırmacılar tarafından görüntülenebilmektedir. Turizm tarihinin konusuna giren belgeler de arşivde geniş yer tutmaktadır. Aşağıdaki tabloda turizm tarihinin konusuna girebilecek bazı arama kavramlarını çıkardık ve bu kavramlarla ilgili arşivde karşımıza çıkan belge miktarını belirledik. Bu meyanda dikkatimizi çeken bazı hususları da turizm tarihi çalışması yapan araştırmacılarla paylaşmayı görev saymaktayız. Malum olduğu üzere turizm ve turist kavramları 19. yüzyıl gibi geç bir zaman dilimine aittir. Haliyle bu konularda belge arayan araştırmacıların modern tabirlerle arşivden belge arayıp bulması çok zordur. Örnek vermek gerekirse arşivde "turist" kavramıyla arama yaptığımızda 104 belgeye ulaşırken "turist"le yakın anlamda olan ve Osmanlı Devleti zamanında daha fazla tercih edilen "züvvar" (ziyaretçiler) kelimesinden 211 belgeye ulaşılabilmekteyiz. Ayrıca "taramayı "zuvvar" olarak yaptığımızda 174 belgeye daha erişilebilmektedir. Öte yandan Osmanlı Devleti'nden bugüne ulaşan çeşitli belgelerde bazı kavramlar Türkçe ya da Arapçasıyla kullanabilmektedir. Benzer şekilde bazı kavramların Farsçası, hatta birçok dilde aramasıyla da belirli sonuçlar elde edilebilmektedir. Örneğin "yol" kavramiyla ilgili bir taramada 64144 adet belgeye ulaşılırken, "yol" kelimesinin Arapçası "tarik" kavramiyla yapılan taramada 9341, "tarik" kelimesinin çoğulu "turuk" kelimesiyle yapılan taramada 3022 ve "şose" kavramıyla yapılan taramada 2294 belge daha çıkabilmektedir. Hazırladığımız listenin araştırmacılara bir fikir vereceği umudunu taşıyoruz. Gelecek sayıda Devlet arşivleri içerisinde yer alan Cumhuriyet Arşivindeki belge türleri ve Turizm Tarihinde kullanımını değerlendirmeye gayret edeceğiz.

\section{KAYNAKÇA}

Akyıldız, A. (1998). Yakınçağ Osmanlı Sosyo-Ekonomik Tarihi Araştırmalarında Kaynak Sorunları: Arşiv ve Arşiv Dışı Malzemenin Önemi, İslam Araştırmaları Dergisi, 2: 165-170.

Anadolu Ajans1, https://www.aa.com.tr/tr/kultur-sanat/osmanlinin-hafizasi-buyuk-tehlike-atlatmis/83108, Erişim tarihi: 15 Ekim 2021.

Binark, İ. (1994). Türk Arşivlerinin Kısa Tarihçesi ve Devlet Arşivleri Genel Müdürlüğ̈̈nün Faaliyetleri. Ankara: Devlet Arşivleri Genel Müdürlüğü Yayını.

Rukancı, F. (2008). Osmanlı Devleti'nde Arşivcilik Çalışmalar1, Türk Kütüphaneciliği, 22 (4): 414-434.

Türkiye Cumhuriyeti Cumhurbaşkanlığ 1 Devlet Arşivleri Başkanlığı, https://www.devletarsivleri.gov.tr/Sayfalar/ Sayfa.aspx?icerik=9E $h=A D A 45 D 7 B 737 C B C 58 F 13 C 672 C$ 0AECCA8E9F0DDB54A7AB8426349949A5FDEB9E15, Erişim tarihi: 10 Ekim 2021.

Yazarsız (2017). Başbakanlık Osmanlı Arşivi Rehberi. İstanbul: T.C. Başbakanlık Devlet Arşivleri Genel Müdürlüğü Osmanlı Arşivi Daire Başkanlığı Yayını. 

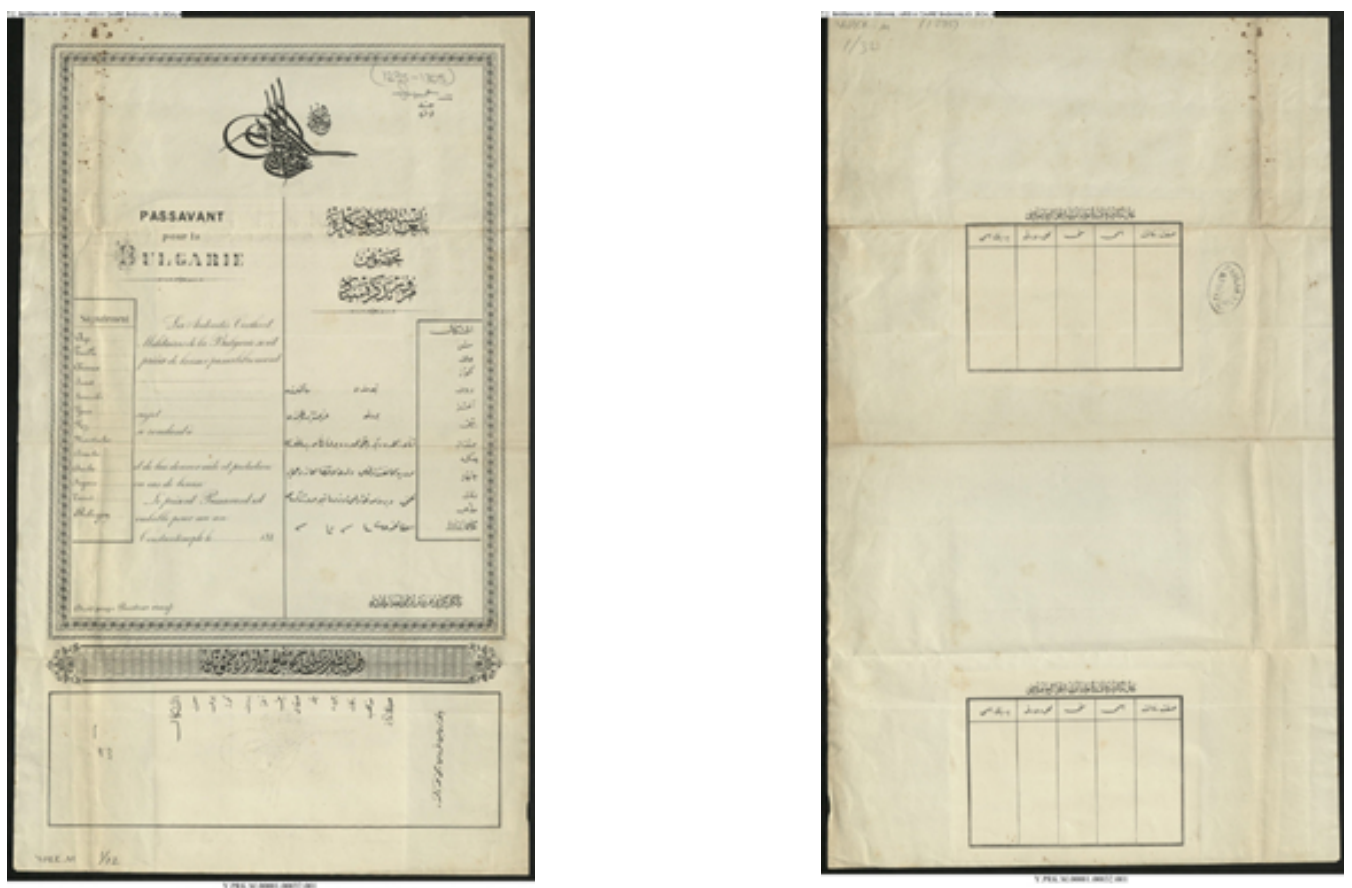

Belge 1. BOA.Y.PRK.M.00001.00032.001-Bulgaristan'a gideceklere mahsus mürûr tezkeresi (H. 29 Zilhcce 1295/M.24 Aralık 1878 tarihli)-Tezkere Osmanlı Türkçesi ve Fransızca dillerinde düzenlenmiștir. Tezkerede sahibinin ismi, eşkâli, yaşı, boyu, gözü, burnu, ağzı, bıyı̆̆ı, sakalı, çenesi, çehresi, rengi, mezhebi, alamet-i farikası gibi bilgilere yer verilmiştir.
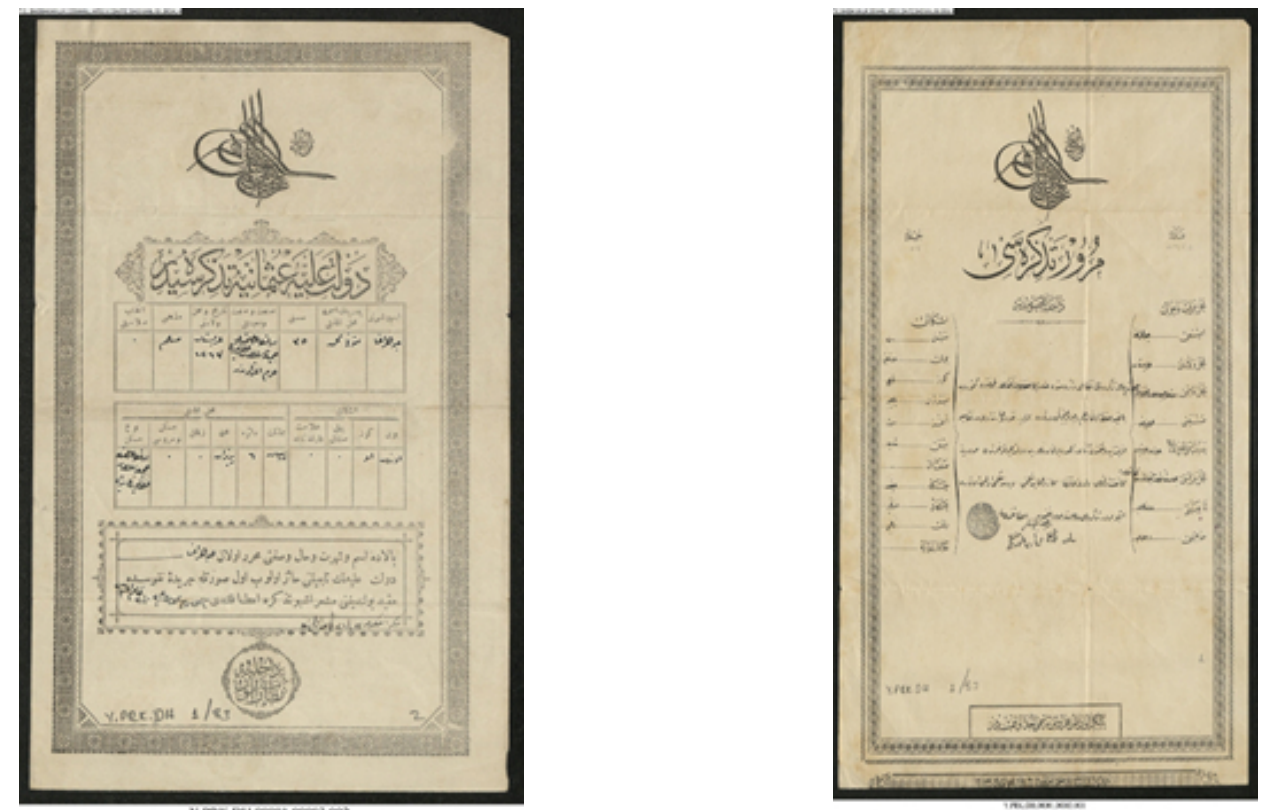

Belge 2. BOA.Y.PRK.DH.00001.00083.002-Cemile Sultan'ın Kethüdâsı Cevher Ağa'ya verilen mürûr tezkiresi (H. 25 Rebülevvel 1302/M. 12 Ocak 1885) 


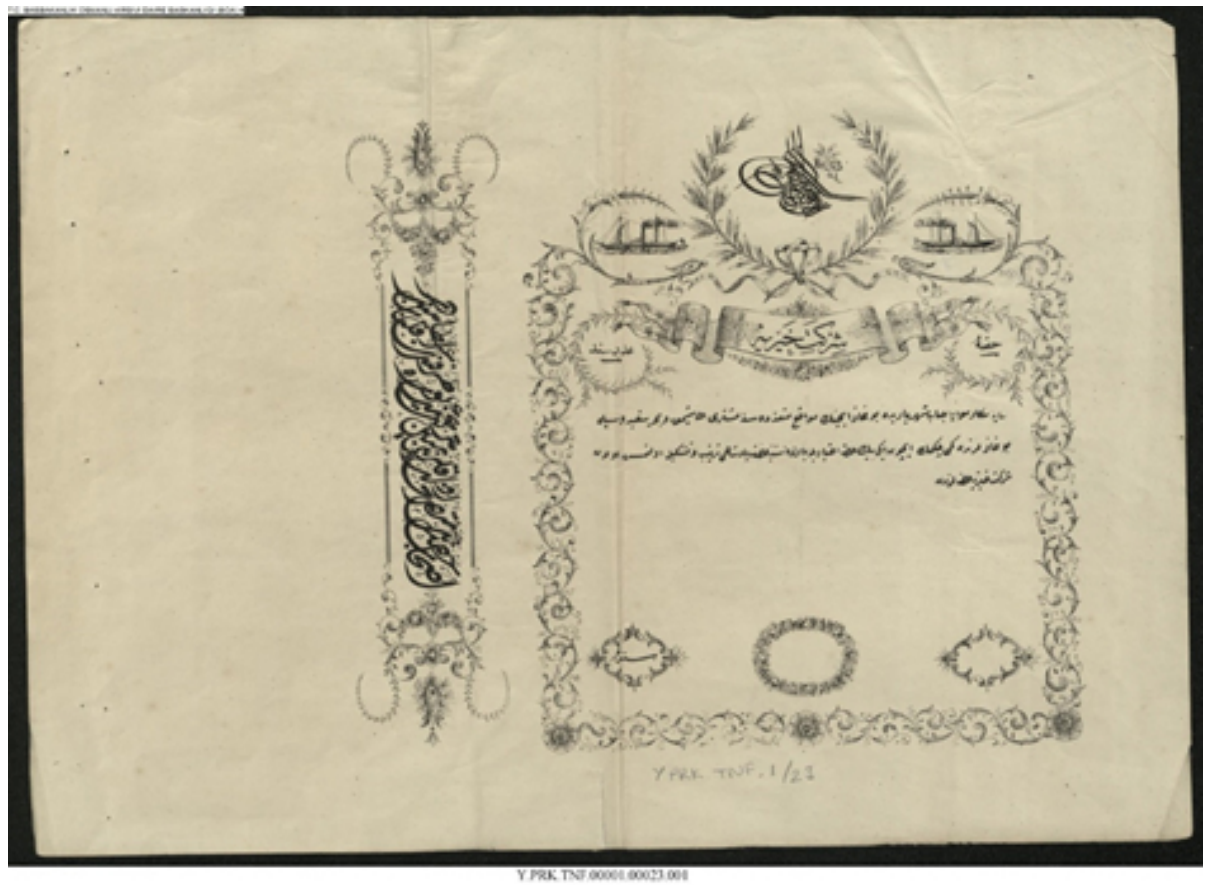

Belge 3. BOA.Y.PRK.TNF.00001.00023.001-Boğaziçi'nde yolcu taşımak ve Bahr-i Sefid (Akdeniz) ve Bahr-i Siyah (Karadeniz) boğazlarında gemi çekmeyi sağlamak için tertip edilen hisse senedi ( $\mathrm{H}$. 23 Şevval 1298/M. 18 Eylül 1881)

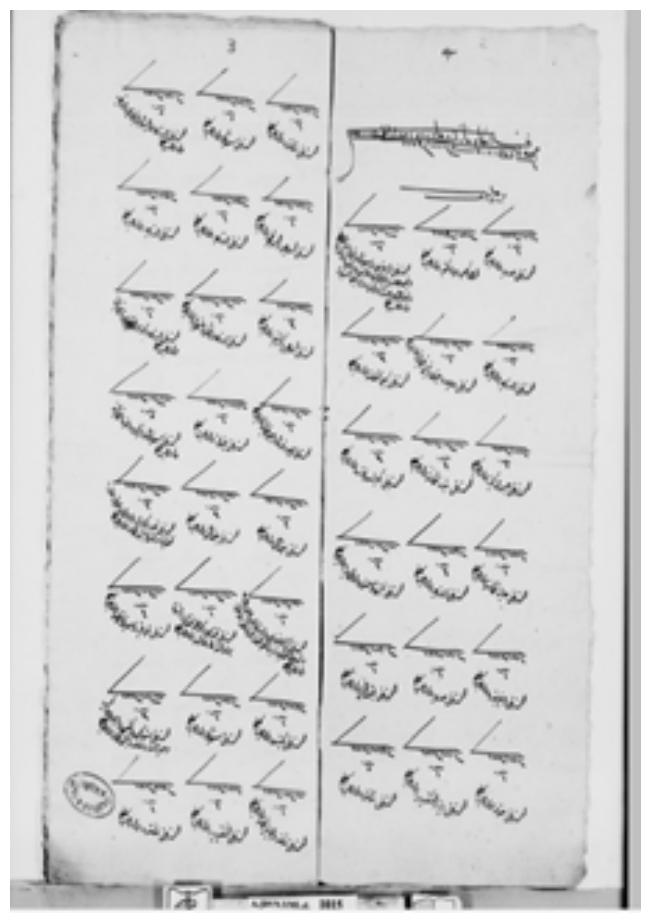

Belge 4. BOA.A.DVN.YML.d.-Bir Menzil ve Yol Defteri Örneği (Bu defterde yollardaki posta menzillerinde duranlar ve aldıkları atlar hakkında bilgiler bulunmaktadir.) 